\title{
Dose-related effects of clozapine and risperidone on the pattern of brain regional serotonin and dopamine metabolism and on tests related to extrapyramidal functions in rats
}

FARHAT BATOOL ${ }^{1, *}$

AMBREEN HASNAT ${ }^{1}$

MUHAMMAD ABDUL HALEEM ${ }^{2}$

DARAKHSHAN JABEEN HALEEM ${ }^{1}$

${ }^{1}$ Neurochemistry and Biochemical

Neuropharmacology Research

Laboratory, Department of Biochemistry

University of Karachi, Karachi-75270

Pakistan

2 Department of Biomedical Engineering Sir Syed University of Engineering and Technology, Karachi, Pakistan
The present study was designed to evaluate the behavioral and neurochemical profiles of clozapine and risperidone in rats in a dose-dependent manner. Animals injected intraperitoneally (i.p.) with clozapine (2.5, 5.0 and $\left.10.0 \mathrm{mg} \mathrm{kg}^{-1}\right)$ or risperidone $\left(1.0,2.5\right.$ and $\left.5.0 \mathrm{mg} \mathrm{kg}^{-1}\right)$ were sacrificed $1 \mathrm{~h}$ later to collect brain samples. Hypolocomotive effects (home cage activity and catalepsy) were successively monitored in each animal after the drug or saline administration. Both drugs significantly $(p<0.01)$ decreased locomotor activity at high doses and in a dose-dependent manner. Maximum (100\%) cataleptic potential was achieved at a high dose $\left(5.0 \mathrm{mg} \mathrm{kg}^{-1}\right)$ of risperidone. Neurochemical estimations were carried out by HPLC with electrochemical detection. Both drugs, at all doses, significantly $(p<0.01)$ increased the concentration of homovanillic acid (HVA), a metabolite of dopamine (DA), in the striatum. Dihydroxyphenylacetic acid (DOPAC) levels increased in the striatum and decreased in the rest of the brain, particularly in clozapine-injected rats. 5-Hydroxyindoleacetic acid (5-HIAA), the predominant metabolite of serotonin, significantly $(p<0.01)$ decreased in the striatum. 5-Hydroxytryptamine (5-HT) was significantly $(p<0.01)$ increased by risperidone and decreased by clozapine in the rest of the brain. Striatal tryptophan (TRP) was significantly $(p<0.01)$ decreased by risperidone and increased in the rest of the brain. The striatal HVA/DA ratio increased and the 5-HT turnover rate remained unchanged in the rest of the brain. Results suggest that the affinity of the two drugs towards $\mathrm{D}_{2} / 5-\mathrm{HT}_{1 \mathrm{~A}}$ receptors interaction is involved in lower incidence of extrapyramidal side effects. Role of $5-\mathrm{HT}_{1 \mathrm{~A}}$ receptors in the treatment of schizophrenia is discussed.

Keywords: atypical antipsychotics, dopamine $\mathrm{D}_{2}$ receptors, extrapyramidal side effects, serotonin ${ }_{1 \mathrm{~A}}$ receptors, schizophrenia

\footnotetext{
* Correspondence; e-mail: batool@uok.edu.pk
} 
F. Batool et al.: Dose-related effects of clozapine and risperidone on the pattern of brain regional serotonin and dopamine metabolism and on tests related to extrapyramidal functions in rats, Acta Pharm. 60 (2010) 129-140.

Schizophrenia is one of the most severe and debilitating psychiatric diseases. The introduction of antipsychotic drugs was indisputably a great advance in the pharmacotherapy of mental disorders (1). Typical and atypical neuroleptics have been differentiated on the basis of their ability to enhance dopamine (DA) release in different meso-telencephalic DA projections. Atypicality has been ascribed to serotonin (5-hydroxytryptamine, 5-HT) and DA (5- $\left.\mathrm{HT}_{2} / \mathrm{D}_{2}\right)$ antagonism that may be involved in the antipsychotic effect (2). A majority of schizophrenic patients respond to classical neuroleptic drugs, which are believed to act largely via the blockade of dopamine $\mathrm{D}_{2}$ receptors in limbic structures (3). Moreover, the concomitant blockade of $\mathrm{D}_{2}$ receptors in the basal ganglia has been associated with the appearance of extrapyramidal side effects (EPS) $(2,3)$. The typical effect of administering a DA receptor antagonist is suppression of spontaneous locomotor behavior and elicitation of a state known as catalepsy (4). Selective antagonists of DA-D 2 receptors can elicit catalepsy $(3,4)$. Moreover, receptors on the striatum appear to play an important role in the elicitation of catalepsy (4). The dopamine system has traditionally been considered fundamental to the control of motor activity (5). With respect to the anatomical site of action, a view has developed that the striatum is involved in the control of extrapyramidal motor functions. A survey of clinical literature shows that haloperidol is very likely to produce EPS, clozapine is relatively unlikely and risperidone is somewhat mild in terms of the production of these effects (6). In comparison with classical neuroleptics, atypical antipsychotic drugs such as, for example, clozapine and risperidone have been found to possess improved efficacy against negative symptomatology and to cause reduced incidence of EPS in clinically effective doses $(5,6)$. The present work was undertaken in an attempt to gain further insights into the mechanisms of action of atypical antipsychotic drugs.

Clozapine, the first atypical antipsychotic, has been reported to be effective in approximately one third or two thirds of patients with a treatment resistant disease (7). Obviously, a goal of the current neuroleptic research is to develop antipsychotic compounds with low incidence of EPS and agranulocytosis. One of the approaches in this context has been to determine neurochemical/pharmacological correlates of clozapine and other atypical neuroleptics. A notable feature of the pharmacology of clozapine is its affinity for serotonergic receptors, particularly $5-\mathrm{HT}_{2 \mathrm{~A}}, 5-\mathrm{HT}_{2 \mathrm{C}}$ and $5-\mathrm{HT}_{1 \mathrm{~A}}$ receptors (8). Risperidone, a benzisoxazol derivative, provided further evidence that potent $5 \mathrm{HT}_{2 \mathrm{~A}}$ antagonism combined with milder $\mathrm{D}_{2}$ antagonism (9) resulted in significantly improved clinical properties (10). Indeed, in addition to successful treatment of the positive symptoms, risperidone markedly improved the negative symptoms of schizophrenia with a low liability of EPS $(2,3,11)$. Other authors have shown that the main reason for the development of atypical antipsychotics was to provide an antipsychotics treatment option that was free of EPS and, further, to reduce the risk of tardive dyskinesia (12).

The primary objective of the present study was, therefore, to compare the effects of various doses of clozapine and risperidone on extrapyramidal motor functions and on brain serotonin and DA metabolism. Homovanillic acid (HVA) and dihydroxyphenyl acetic acid (DOPAC) are the predominant metabolites of DA, while 5-hydroxyindole acetic acid (5-HIAA) is the predominant metabolite of 5-HT. Hence, in the present study, the effects of clozapine and risperidone on HVA/DA and 5-HIAA/5-HT ratios are also compared. 
F. Batool et al:: Dose-related effects of clozapine and risperidone on the pattern of brain regional serotonin and dopamine metabolism and on tests related to extrapyramidal functions in rats, Acta Pharm. 60 (2010) 129-140.

\section{EXPERIMENTAL}

\section{Animals}

The protocol for experimentation was approved and performed in strict accordance with the Guide for the Care and Use of Laboratory Animals (Institute of Laboratory Animal Resources on Life Sciences, US National Research Council, 1996) and the Institutional Animal Ethics Committee (University of Karachi, Pakistan). The guidelines of IAEC, the governing body for animal experimentations in Pakistan, were strictly adhered to during the whole animal experimentation protocol. Locally bred male albino Wistar rats with an average body mass of $180 \pm 20 \mathrm{~g}$ (from Agha Khan University, Karachi, Pakistan) were fed a standard diet and allowed water ad libitum. The animals were group-housed (two rats per cage) in an environmentally controlled room (ambient temperature $24 \pm 2$ ${ }^{\circ} \mathrm{C}$ and relative humidity $55 \pm 5 \%$ ) on a 12:12 h light/dark cycle (lights on at 7:00 a.m.). A 5-day acclimatization period was allowed before animals were used in experiments. After this period, and $24 \mathrm{~h}$ before the behavioral tests, the animals were individually housed in an environmentally controlled test room in transparent Perspex cages (dimensions $26 \times 26 \times 26 \mathrm{~cm}$ ) in order to avoid any false effect.

\section{Drugs and injections}

Clozapine (Sigma, Germany) was dissolved in a minimal volume of $0.1 \mathrm{~mol} \mathrm{~L}^{-1}$ acetic acid and $\mathrm{pH}$ was adjusted to 6.5 by $\mathrm{NaOH}$ and diluted with physiological saline $(0.9 \%$ $\mathrm{NaCl}$ ) to desired concentrations of 2.5, 5.0 and $10.0 \mathrm{mg} \mathrm{mL}^{-1}$ and injected in volumes of $1.0 \mathrm{~mL} \mathrm{~kg}^{-1}$ body mass. Risperidone (Janssen, USA) was dissolved in $0.4 \mathrm{~mol} \mathrm{~L}^{-1}$ tartaric acid and $\mathrm{pH}$ was adjusted to 6.5 by $\mathrm{NaOH}$ and diluted with saline to the desired concentrations of 1.0, 2.5 and $5.0 \mathrm{mg} \mathrm{mL}^{-1}$ and injected in volumes of $1.0 \mathrm{~mL} \mathrm{~kg}^{-1}$ body mass. Control animals received equal volum of vehicle $\left(0.1 \mathrm{~mol} \mathrm{~L}-1\right.$ acetic acid, $0.1 \mathrm{~mol} \mathrm{~L}^{-1}$ $\mathrm{NaOH}$ and/ or $0.4 \mathrm{~mol} \mathrm{~L}^{-1}$ tartaric acid and saline in the ratio 1:1:8). The animals were injected following a balanced pattern between 10:00 and 11:00 $\mathrm{h}$ and the route of administration used for vehicle and drugs was intraperitoneal (i.p.). Motor activity was monitored for $10 \mathrm{~min}$ starting $10 \mathrm{~min}$ after injections. Catalepsy effects of the drugs were scored for a cut-off time of 3 min starting 30 min post injections and animals were killed to collect brain samples $1 \mathrm{~h}$ after injections. All the reagents used during the study were of analytical grade.

\section{Behavioral study}

Dose-related motor effects of clozapine and risperidone. - Motor-related effects of the drugs were monitored in Perspex activity cages. Animals were transferred to Perspex activity cages with saw dust-covered floor $15 \mathrm{~min}$ before injecting the saline or drug. Experiment was conducted in a separate quiet room. Motor activity in the activity box was monitored under white light as the number of cage crossings per $10 \mathrm{~min}$ starting $10 \mathrm{~min}$ post injections (13).

Dose-related cataleptic effects of clozapine and risperidone. - Catalepsy, defined as the acceptance and retention of abnormal posture, was measured by means of a bar test. Bar 
F. Batool et al.: Dose-related effects of clozapine and risperidone on the pattern of brain regional serotonin and dopamine metabolism and on tests related to extrapyramidal functions in rats, Acta Pharm. 60 (2010) 129-140.

test determinations were carried out by gently removing rats from their home cages and placing their forepaws over a horizontal bar, fixed at a height of $10 \mathrm{~cm}$, with heads of animals upwards on an inclined surface at an angle of $60^{\circ}$ with the hind limbs abducted (14). The length of time during which the animal retained this position was recorded by measuring the time from the placement of the rat until removal of one of its forepaws. The animal to be tested was placed on an inclined surface $\left(26 \times 40 \mathrm{~cm}, 60^{\circ}\right.$ inclination) for a cut-off time of $3 \mathrm{~min}(180 \mathrm{~s})$. A control rat changes its position immediately on the inclination. Time (in s) during which drug or saline injected animals remained immobile on the inclination was monitored. Animals not moving on the inclined surface up to 3 min were put back in their cages. To better measure the catalepsy (avoiding false results), the animals were tested twice at each time interval and only the longest duration of time was recorded. The cataleptic score was calculated as [latency of movement (s)/cut-off time (180 s)] 100.

\section{Neurochemical analysis}

Dissection of the striatum. - Saline, clozapine or risperidone injected animals were killed $1 \mathrm{~h}$ post injections. The dissection procedure was essentially the same as described elsewhere $(15,16)$. A fresh brain was dipped into ice-cold saline and placed with its ventral side up in the molded cavity of a brain slicer. Fine fishing line wire was inserted into the slots of the slicer to give slices of $2 \mathrm{~mm}$ thickness. The slice containing the striatum was transferred to a slide kept on ice. Punches of $2.5 \mathrm{~mm}$ diameter were made bilaterally in the striatum to collect the brain region. The striatum, also known as striate body, neostriatum or striate nucleus, is a subcortical (i.e., inside, rather than outside) part of the telencephalon/cerebrum. It is the major input station of the basal ganglia system. In primates (including humans), the striatum is divided by a white matter tract called the internal capsule into two sectors, called the caudate nucleus and putamen. The rest of the brain was also stored for the biogenic amine assay. The samples were stored at $-70{ }^{\circ} \mathrm{C}$ for the estimation of DOPAC, DA, HVA, 5-HIAA and 5-HT by high performance liquid chromatography with electrochemical detection (HPLC-EC) $(17,18)$.

HPLC-EC analysis. - Biogenic amines and their major metabolites were extracted with $150 \mu \mathrm{L}$ of perchloric acid (70\%) from brain tissue punches $(<250 \mu \mathrm{g})$ using a simple one-step sample preparation method (19). A 5- $\mu \mathrm{m}$ (particle size) ODS column (4.0 mm i.d. and $250 \mathrm{~mm}$ length) was used. Mobile phase comprising methanol (14\%), octyl sodium sulphate $(0.023 \%)$ and EDTA $(0.0035 \%)$ in $0.1 \mathrm{~mol} \mathrm{~L}^{-1}$ phosphate buffer of $\mathrm{pH} 2.9$ was passed through the column at a constant flow rate $\left(1.0 \mathrm{~mL} \mathrm{~min}^{-1}\right)$ with the help of a Waters 510 HPLC pump (Waters Corporation, USA). Electrochemical detection was achieved on a Shimadzu L-EC 6A detector (Shimadzu, Japan) at an operating potential of $0.8 \mathrm{~V}$. Tryptophan was determined in a separate run at an operating potential of $1.0 \mathrm{~V}$ (17-19). This method was employed to study the effects of intraperitoneal administration of clozapine and risperidone on biogenic amines in a number of discrete rat brain regions.

\section{Statistical analysis}

All behavioral and neurochemical parameters were calculated for each animal, and the data was presented as arithmetic mean \pm standard deviation. Statistical analysis was 
F. Batool et al:: Dose-related effects of clozapine and risperidone on the pattern of brain regional serotonin and dopamine metabolism and on tests related to extrapyramidal functions in rats, Acta Pharm. 60 (2010) 129-140.

performed using one-way ANOVA (analysis of variance) and post-hoc comparison was made by the Newman-Keuls test.

\section{RESULTS AND DISCUSSION}

The results of the experiments examining the dose-related effects of clozapine and risperidone on behavioral deficits are shown in Fig. 1. ANOVA showed significant effects of clozapine (2.5, 5.0 and $\left.10.0 \mathrm{mg} \mathrm{kg}^{-1}\right)$ and risperidone $\left(1.0,2.5\right.$ and $\left.5.0 \mathrm{mg} \mathrm{kg}^{-1}\right)$ on motor activity $(p<0.01)$ and on catalepsy $(p<0.01)$. Our data showed that all the doses of clozapine and risperidone decreased motor activity in a dose-dependent manner (Fig. 1). Both drugs were found cataleptogenic only at high doses. However, hypolocomotive effects of both drugs were found $100 \%$ only at high doses of clozapine $\left(5.0 \mathrm{mg} \mathrm{kg}^{-1}\right)$ and risperidone $\left(10.0 \mathrm{mg} \mathrm{kg}^{-1}\right)$. Post-hoc analysis showed that maximum (100\%) catalepsy occurred only at a dose of $10.0 \mathrm{mg} \mathrm{kg}^{-1}$ clozapine and $5.0 \mathrm{mg} \mathrm{kg}^{-1}$ of risperidone when compared with the respective saline-treated rats. The most important finding of the present study is that clozapine did not decrease locomotor activity at a dose of $2.5 \mathrm{mg} \mathrm{kg}-1$. No catalepsy was observed at doses of $2.5 \mathrm{mg} \mathrm{kg}^{-1}$ and $5.0 \mathrm{mg} \mathrm{kg}^{-1}$ clozapine. Akinesia and $62 \%$ catalepsy were produced only at the cataleptogenic dose of $10.0 \mathrm{mg} \mathrm{kg}^{-1}$ of clozapine.

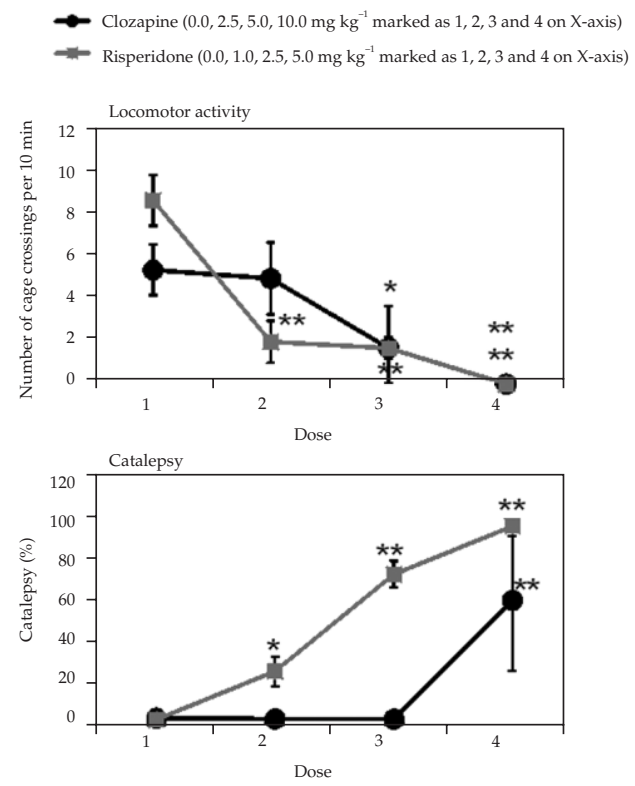

Fig. 1. Dose-related effects of clozapine and risperidone on motor activity and cataleptic potential. Values are mean $\pm \mathrm{SD}(n=12)$. Significant differences by the Newman-Keuls test: ${ }^{*} p<0.05,{ }^{* *} p<0.01$ compared to respective saline-treated rats following one-way ANOVA. 
An important finding of the present study is that acute administration of risperidone relatively uniformly increases DA release and metabolism in the striatum region of rat brain. The proposed mechanism of HVA changes involves acute blockade of pre- and postsynaptic $\mathrm{D}_{2}$ receptors $(3,20)$. It has been reported that only the postsynaptic DA- $\mathrm{D}_{2}$ receptors are blocked by antipsychotics drugs in direct relation to their clinical antipsychotic potencies. No drug has been identified with antipsychotic action without a significant affinity for $\mathrm{D}_{2}$ receptors. The present study, therefore, implies that the blockade of the DA- $\mathrm{D}_{2}$ receptors and responsiveness of $5-\mathrm{HT}_{1 \mathrm{~A}}$ receptors produce antischizophrenic effects. The apparently low occupancy of $\mathrm{D}_{2}$ receptors by clozapine suggests that $\mathrm{D}_{2}$ is not the major antipsychotics target; in addition, also atypical antipsychotics have affinities for 5 -HT receptors and may by involved in their ability to produce fewer EPS (20). In addition, it is possible that the relative lack of EPS motor effects with clozapine and risperidone administration in the present study could be related to the two-way interaction between DA and 5-HT receptors. Fig. 2 shows the effects of various doses of clozapine and risperidone on the levels of dopamine (DA), metabolites dihydroxyphenylacetic acid (DOPAC) and homovanillic acid (HVA), and 5-hydroxyindoleacetic acid (5-HIAA) in the striatum. ANOVA showed significant effects of clozapine on the levels of DA $(p<0.01)$, HVA $(p<0.01)$, DOPAC $(p<0.05)$ and 5-HIAA $(p<0.05)$. Effects of risperidone were also significant for HVA $(p<0.05)$. Effects of risperidone on DA, DOPAC and 5-HIAA were not significant. Comparison with post-hoc analysis showed
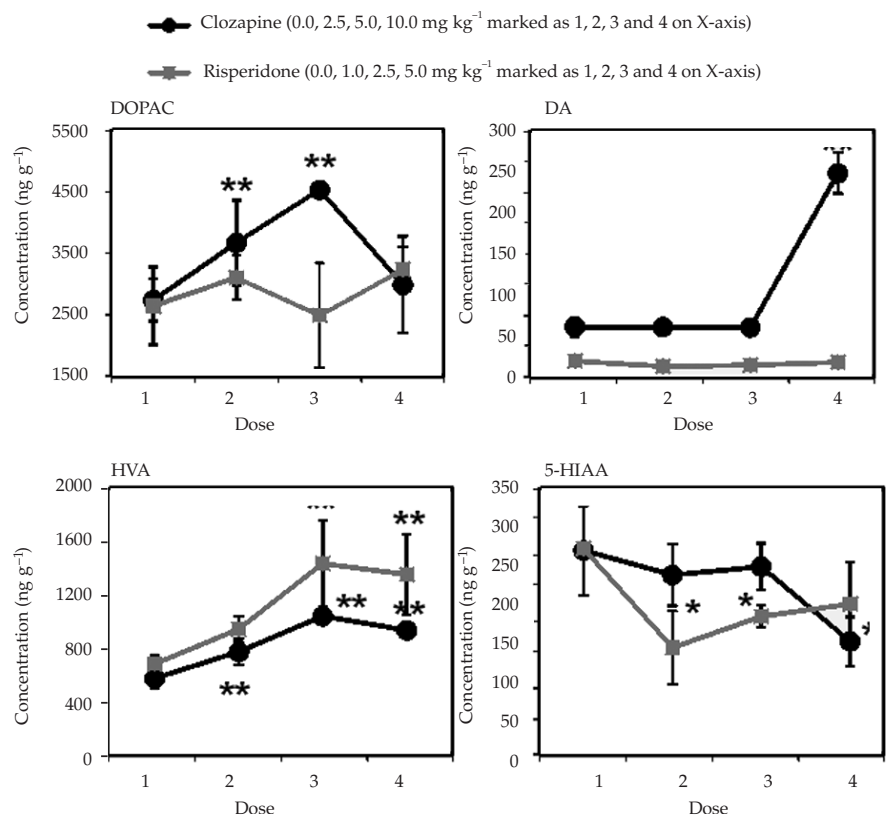

Fig. 2. Dose-related effects of clozapine and risperidone on the levels of DOPAC, DA, HVA and 5 -HIAA in the rat striatum. Values are mean \pm SD $(n=12)$. Significant differences by Newman-Keuls test: ${ }^{*} p<0.05,{ }^{* *} p<0.01$ compared to respective saline-treated rats following one-way ANOVA. 
that the effects of risperidone on DOPAC changes were not significant when compared to the respective controls. Rats injected with $2.5 \mathrm{mg} \mathrm{kg}^{-1}$ and $5.0 \mathrm{mg} \mathrm{kg}^{-1}$ risperidone exhibited pronounced 2-3 fold increases in HVA concentration and these increases were also comparable when measured against saline-treated animals. HVA levels were also increased following the administration of clozapine and reached a maximum at a dose of $5.0 \mathrm{mg} \mathrm{kg}^{-1}$. Maximum increases of HVA were higher in risperidone than clozapine injected animals. It is now generally agreed that the clinical response to neuroleptics is associated with an increase in HVA concentration (21) and the observed increases of HVA, particularly in the striatum (Fig. 2), are taken as distinguished clinical features of both drugs in the treatment of psychosis. The concentration of DOPAC also increased following the administration of clozapine at doses of 2.5 and $5.0 \mathrm{mg} \mathrm{kg}^{-1}$. DOPAC levels did not increase at the cataleptogenic dose of $10.0 \mathrm{mg} \mathrm{kg}^{-1}$ of clozapine. 5-HIAA levels increased following the administration of a high dose of risperidone but these increases were insignificant. Conversely, clozapine administration did decrease 5-HIAA concentration only at the high dose of $10.0 \mathrm{mg} \mathrm{kg}^{-1}$. The decreases by clozapine that were not
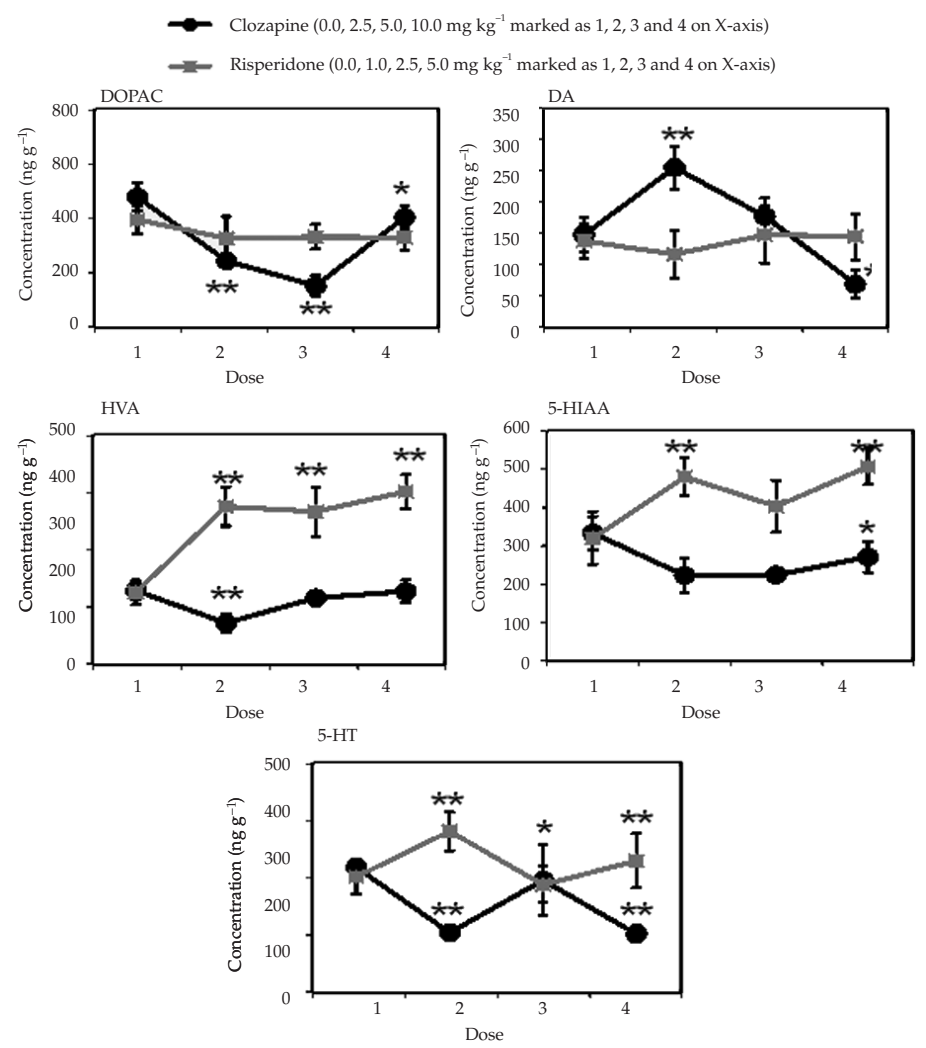

Fig. 3. Dose-related effects of clozapine and risperidone on the levels of DOPAC, DA, HVA, 5-HIAA and $5-\mathrm{HT}$ in the rest of the brain. Values are mean $\pm \mathrm{SD}(n=12)$. Significant differences by the Newman-Keuls test: ${ }^{*} p<0.05,{ }^{* *} p<0.01$ compared to respective saline-treated rats following one-way ANOVA. 
significant at doses of $2.5 \mathrm{mg} \mathrm{kg}^{-1}$ and $5.0 \mathrm{mg} \mathrm{kg}^{-1}$ were significant $(p<0.01)$ at the cataleptogenic dose of $10.0 \mathrm{mg} \mathrm{kg}^{-1}$.

Data analyzed by ANOVA regarding the levels of DOPAC, DA, HVA, 5-HIAA and 5-HT in the rest of the brain are illustrated in Fig. 3. Significant effect of clozapine on DOPAC $(p<0.01)$, DA $(p<0.01)$, HVA $(p<0.01)$, 5-HT $(p<0.01)$ and 5-HIAA $(p<0.05)$ concentrations was evident. Effects of risperidone were only significant for $\operatorname{HVA}(p<0.01)$, 5-HIAA $(p<0.01)$ and 5-HT $(p<0.01)$ and not significant for DOPAC and DA. Post-hoc comparison by the Newman-Keuls test showed that risperidone significantly increased HVA levels in a dose-dependent manner and all the increases were comparable when measured against the respective saline-treated group of rats. Conversely, clozapine significantly decreased HVA concentration only at a dose of $2.5 \mathrm{mg} \mathrm{kg}^{-1}$. The decreases were not significant at higher doses of clozapine (5.0 and $10.0 \mathrm{mg} \mathrm{kg}^{-1}$ ). Concentration of DOPAC also decreased following the administration of clozapine at doses of 2.5 and $5.0 \mathrm{mg} \mathrm{kg}^{-1}$ but not at the cataleptogenic dose of $10.0 \mathrm{mg} \mathrm{kg}^{-1}$. Concentration of 5-HIAA and 5-HT increased following the administration of risperidone at doses of 1.0 and 5.0 $\mathrm{mg} \mathrm{kg}^{-1}$ but not at dose of $2.5 \mathrm{mg} \mathrm{kg}^{-1}$. Clozapine, at all doses, significantly decreased
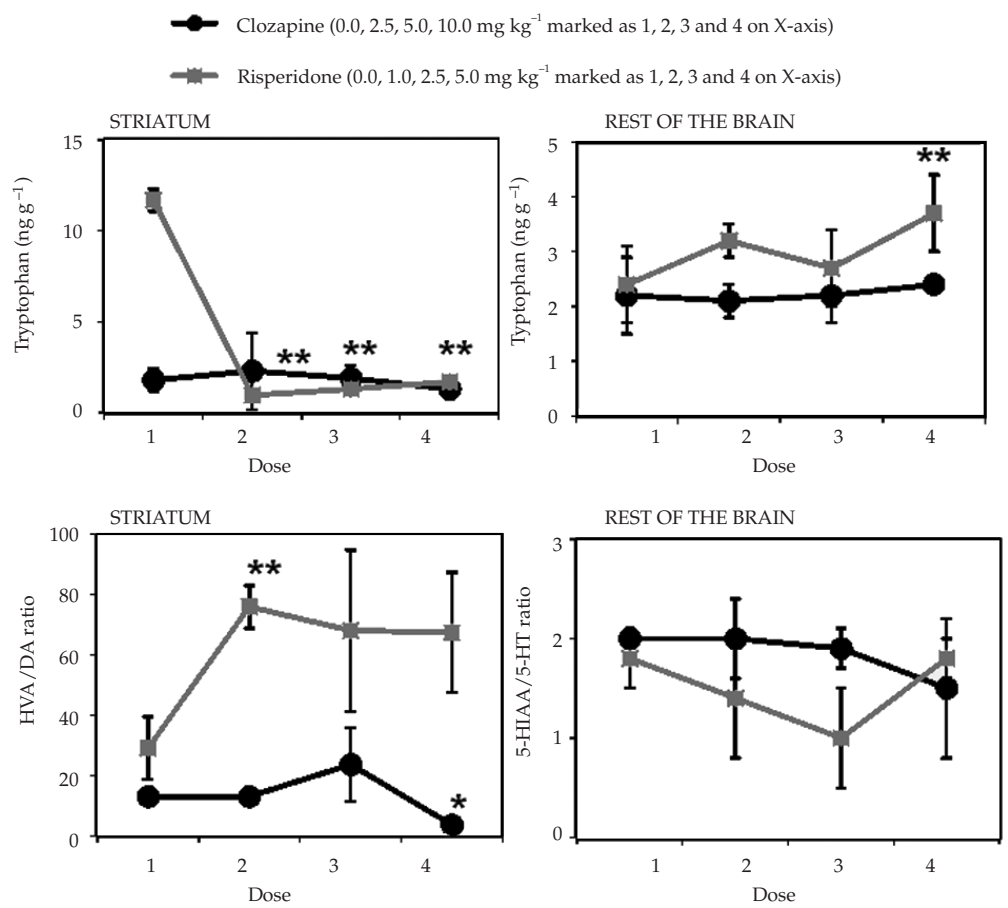

Fig. 4. Dose-related effects of clozapine and risperidone on the levels of tryptophan, HVA/DA and 5-HIAA/5-HT ratios in the striatum and the rest of the brain. Values are mean $\pm \mathrm{SD}(n=12)$. Significant differences by the Newman-Keuls test: ${ }^{*} p<0.05,{ }^{* *} p<0.01$ compared to respective saline-treated rats following one-way ANOVA. 
F. Batool et al.: Dose-related effects of clozapine and risperidone on the pattern of brain regional serotonin and dopamine metabolism and on tests related to extrapyramidal functions in rats, Acta Pharm. 60 (2010) 129-140.

the levels of 5-HIAA in the striatum and the rest of the brain. 5-HT levels were also significantly decreased at doses of 2.5 and $10.0 \mathrm{mg} \mathrm{kg}^{-1}$ in the rest of the brain (Fig. 3).

Serotonergic mechanisms are also known to influence neuroleptic-induced catalepsy $(21,22)$. The serotonergic effects of clozapine have been also emphasized as possibly being related to the unique clinical characteristics of clozapine $(22,23)$, and it was recently suggested that the $5-\mathrm{HT}_{2 \mathrm{~A}} / \mathrm{D}_{2}$ binding ratio could be used to distinguish between typical and atypical antipsychotics. A decrease in 5-HT metabolism by clozapine is explicable in terms of the drug moderate affinity for $5-\mathrm{HT}_{1 \mathrm{~A}}$ receptors. Tissue measurements of regional DA and 5-HT metabolism in the rat brain have indicated that risperidone affects the DA turnover in both mesolimbic and nigrostriatal terminal regions and, to some extent, also 5-HT metabolism in these target areas (23-25). The dose-related effects of clozapine and risperidone on the levels of tryptophan and the ratio HVA/DA and 5-HIAA/5-HT in the striatum and the rest of the brain are depicted in Fig. 4. ANOVA performed on striatal data showed a significant effect of risperidone on TRP $(p>0.05)$ and insignificant for HVA/DA $(p>0.05)$ ratio. Effects of clozapine were insignificant for TRP and significant for HVA/DA ratio. Data on the rest of the brain showed an insignificant effect of risperidone on TRP $(p>0.05)$. Post-hoc analysis showed that the ratio HVA/DA decreased in the striatum of clozapine injected rats compared to saline-treated rats and the decreases were not significant at doses of 2.5 and $5.0 \mathrm{mg} \mathrm{kg}^{-1}$ but were significant at the dose of $10.0 \mathrm{mg} \mathrm{kg}^{-1}$. Conversely, the 5-HT turnover rate remained unaltered following the administration of clozapine. Administration of risperidone significantly increased the HVA/DA ratio at a low dose $\left(1.0 \mathrm{mg} \mathrm{kg}^{-1}\right)$. ANOVA performed on the data of the rest of the brain showed insignificant effects of clozapine and risperidone on TRP and the 5-HIAA/5-HT ratio. Post-hoc test showed non-significant decreases at the 5-HIAA/5-HT ratio following the administration of clozapine and risperidone compared to saline-treated rats. Results revealed that levels of 5-HIAA were significantly increased at low $\left(1.0 \mathrm{mg} \mathrm{kg}^{-1}\right)$ and high $\left(5.0 \mathrm{mg} \mathrm{kg}^{-1}\right)$ doses of risperidone in the rest of the brain when compared to saline-treated rats (Fig. 3). In contrast, clozapine administration decreased the 5-HT turnover rate in the rest of the brain at doses of 5.0 and $10.0 \mathrm{mg} \mathrm{kg}^{-1}$. Comparison of the effects of these two drugs shows that increases in HVA concentration in the striatum and decreases in 5-HT in the rest of the brain may be taken as a neurochemical profile of atypical, clozapine-like, activity.

\section{CONCLUSIONS}

In conclusion, the present study shows that both clozapine and risperidone increase the brain regional DA turnover in a comparable manner. The results also suggest that administration of atypical antipsychotics at low doses produces fewer EPS in terms of lower hypolocomotive effects in rats in both familiar and novel environments. This is explainable since drugs that tend towards serotonin receptors are known to be involved in lower EPS production. The effects of both drugs on 5-HT metabolism are quantitatively similar. Both drugs decrease the 5-HT metabolism in the rat brain striatum. Although other atypical neuroleptics could produce different neurochemical effects, depending upon their activity towards different types of DA and serotonin receptors, an increase in the DA:serotonin metabolite ratio, particularly in the striatum, may be taken as a neuro- 
F. Batool et al.: Dose-related effects of clozapine and risperidone on the pattern of brain regional serotonin and dopamine metabolism and on tests related to extrapyramidal functions in rats, Acta Pharm. 60 (2010) 129-140.

chemical profile of atypical, clozapine-like, activity. These results therefore suggest an important role of 5-HT in the treatment of resistant schizophrenia and lower incidence of EPS. Future work will identify better treatments for these symptoms, as well as new antipsychotic agents that do not cause EPS.

Acknowledgments. - The authors thank the Pakistan Science Foundation (PSF/S-KU/ Chem (348) and the University of Karachi, Pakistan, for providing financial assistance.

\section{REFERENCES}

1. S. Miyamoto, G. E. Duncan, C. E. Marx and J. A. Lieberman, Treatments for schizophrenia: a critical review of pharmacology and mechanisms of action of antipsychotic drugs, Mol. Psychiatry 10 (2005) 79-104; DOI: 10.1038/sj.mp.4001556.

2. S. Natesan, G. E. Reckless, K. B. Barlow, J. N. Nobrega and S. Kapur, Amisulpride the 'atypical' atypical antipsychotic-comparison to haloperidol, risperidone and clozapine, Schizophr. Res. 105 (2008) 224-235; DOI: 10.1016/j.schres.2008.07.005.

3. V. Bigliani, R. S. Mulligan, P. D. Acton, D. Visvikis, P. J. Ellm, C. Stephenson, R. W. Kerwin and L. S. Pilowsky, In vivo occupancy of striatal and temporal cortical $D_{2} / D_{3}$ dopamine receptors by typical antipsychotic drugs. [123I] epidepride single photon emission tomography (SPET) study, Brit. J. Psychiat. 175 (1999) 231-238; DOI: 10.1192/bjp.175.3.231.

4. S. Leucht, C. Corves, D. Arbter, R. R. Engel, C. Li and J. M. Davis, Second-generation versus first-generation antipsychotic drugs for schizophrenia: a meta-analysis, Lancet 373 (2009) 31-41; DOI: 10.1016/S0140-6736(08)61764-X.

5. M. L. Wadenberg, S. Kapur, A. Soliman, C. Jones and F. Vaccarino, Dopamine $\mathrm{D}_{2}$ receptor occupancy predicts catalepsy and the suppression of conditioned avoidance response behavior in rats, Psychopharmacology 150 (2000) 422-429; DOI: 10.1007/s002130000466.

6. J. T. Trevitt, M. Lyons, J. Aberman, D. Carriero, M. Finn and J. D. Salamone, Effects of clozapine, thioridazine, risperidone and haloperidol on behavioral tests related to extrapyramidal motor function, Psychopharmacology 132 (1997) 74-81; DOI: 10.1007/s002130050322.

7. S. Kapur and P. Seeman, Does fast dissociation from the dopamine $\mathrm{D}_{2}$ receptor explain the action of atypical antipsychotics?: A new hypothesis, Am. J. Psychiat. 158 (2000) 360-369; DOI: 10.1176/appi.ajp.158.3.360.

8. A. Newman, C. Chaput, L. Verriele and M. J. Millan, Clozapine is a partial agonist at cloned human serotonin 5- $\mathrm{HT}_{1 \mathrm{~A}}$ receptors, Neuropharmacology 35 (1996) 119-121; DOI: 10.1016/0028-3908 (95)00170-0.

9. S. Szymanski, J. Lieberman, S. Pollack, R. Munne, A. Safferman, J. Kane, M. Kronig and T. Cooper, The dopamine-serotonin relationship in clozapine response, Psychopharmacology 112 (1993) S85-S89; DOI: $10.1007 /$ BF02245011.

10. M. Campbell, P. I. Young, D. N. Bateman, J. M. Smith and S. H. Thomas, The use of atypical antipsychotics in the management of schizophrenia, Br. J. Clin. Pharmaco. 47 (1999) 13-22; DOI: 10.1046/j.1365-2125.1999.00849.x.

11. R. Kumar, G. Palit and B. N. Dhawan, Comparative behavioral effects of typical and atypical antipsychotic drugs in rhesus monkey, Eur. J. Pharmacol. 462 (2003) 133-138; DOI: 10.1016/ S0014-2999(02)02957-6.

12. R. A. Bressan, K. Erlandsson, H. M. Jones, R. S. Mulligan, P. J. Ell and L. S. Pilowsky, Optimizing limbic selective $\mathrm{D}_{2} / \mathrm{D}_{3}$ receptor occupancy by risperidone: a [123I]-epidepride SPET study, J. Clin. Psychopharm. 23 (2003) 5-14; DOI: 10.1097/00004714-200302000-00002. 
13. D. J. Haleem, F. Batool, N. H. Khan, N. Kamil, O. Ali, Z. S. Saify and M. A. Haleem, Differences in the effects of haloperidol and clozapine on brain serotonin and dopamine metabolism and on tests related to extrapyramidal functions in rats, Med. Sci. Monit. 8 (2002) 354-361.

14. F. Batool, S. Ahmed and D. J. Haleem, Dietary supplementations of amino acids: evidence for enhanced serotonergic functions following haloperidol withdrawal in rat medial prefrontal cortex, J. Coll. Physicians Surg. Pak. 9 (2009) 139-145.

15. D. J. Haleem, Z. S. Saify, S. Siddiqui, F. Batool and M. A. Haleem, Pre- and postsynaptic responses to 1-(1-naphthylpiperazine) following adaptation to stress in rats, Prog. Neuro-Psychoph. 26 (2002) 149-56; DOI: 10.1016/S0278-5846(01)00240-8.

16. L. S. Pilowsky, D. C. Costa, P. J. Ell, N. P. Verhoeff, R. M. Murray and R. W. Kerwin, $\mathrm{D}_{2}$ dopamine receptor binding in the basal ganglia of antipsychotic-free schizophrenic patients. An 123I-IBZM single photon emission computerized tomography study, Brit. J. Psychiat. 164 (1994) 16-26; DOI: 10.1192/bjp.164.1.16.

17. Q. C. Meng, Y. F. Chen and S. Oparil, A simple method for concentration of biogenic amines and their metabolites from biological samples for analysis by HPLC-EC, Life Sci. 44 (1989) 1207-1213; DOI: 10.1016/0024-3205(89)90316-0.

18. N. Samad, F. Batool and D. J. Haleem, Neurochemical and behavioral effects of 8-OH-DPAT following exposure to restraint stress in rats, Pharmacol. Rep. 59 (2007) 173-180.

19. J. de Jong, U. R. Tjaden, E. Visser and W. H. Meijer, Determination of serotonin and 5-hydroxyindoleacetic acid in urine by reversed-phase ion-pair partition chromatography with fluorimetric detection, J. Chromatogr. 7 (1987) 85-94.

20. L. Farde, A. L. Nordstrom, F. A. Wiesel, S. Pauli, C. Halldin and G. Sedvall, Positron emission tomographic analysis of central $\mathrm{D}_{1}$ and $\mathrm{D}_{2}$ dopamine receptor occupancy in patients treated with classical neuroleptics and clozapine. Relation to extrapyramidal side effects, Arch. Gen. Psychiat. 49 (1992) 538-544; DOI: 10.1016/0024-3205(78)90035-8.

21. T. J. Crow, E. C. Johnstone, A. J. Longden and F. Owen, Dopaminergic mechanisms in schizophrenia: the antipsychotic effect and the disease process, Life Sci. 23 (1978) 563-567; DOI: 10.1016/0024-3205(78)90035-8.

22. D. Pickar, T. P. Su, D. R. Weinberger, R. Coppola, A. K. Malhotra, M. B. Knable, K. S. Lee, J. Gorey, J. J. Bartko, A. Breier and J. Hsiao, Individual variation in $\mathrm{D}_{2}$ dopamine receptor occupancy in clozapine-treated patients, Am. J. Psychiat. 153 (1996) 1571-1578.

23. H. Y. Meltzer and M. Huang, In vivo actions of atypical antipsychotic drug on serotonergic and dopaminergic systems, Prog. Brain Res. 172 (2008) 177-197; DOI: 10.1016/S0079-6123(08)00909-6.

24. X. Xiberas, J. L. Martinot, L. Mallet, E. Artiges, C. Loc'H, B. Mazière and M. L. Paillère-Martinot, Extrastriatal and striatal $\mathrm{D}_{2}$ dopamine receptor blockade with haloperidol or new antipsychotic drugs in patients with schizophrenia, Brit. J. Psychiat. 179 (2001) 503-508; DOI: 10.1192/ bjp.179.6.503.

25. S. Nyberg, L. Farde, L. Eriksson, C. Halldin and B. Eriksson, 5-HT $\mathrm{H}_{2}$ and $\mathrm{D}_{2}$ dopamine receptor occupancy in the living human brain. A PET study with risperidone, Psychopharmacology 110 (1993) 265-272; DOI: 10.1007/BF02251280. 
F. Batool et al:: Dose-related effects of clozapine and risperidone on the pattern of brain regional serotonin and dopamine metabolism and on tests related to extrapyramidal functions in rats, Acta Pharm. 60 (2010) 129-140.

$S A \check{Z} E T A K$

\begin{abstract}
O dozi ovisni učinci klozapina i risperidona na metabolizam serotonina i dopamina u pojedinim područjima mozga i na ekstrapiramidalne nuspojave $u$ štakora
\end{abstract}

\author{
FARHAT BATOOL, AMBREEN HASNAT, MUHAMMAD ABDUL HALEEM i DARAKHSHAN JABEEN HALEEM
}

Cilj rada bio je procjena ponašanja i neurokemijskog profila klozapina i risperidona $\mathrm{u}$ ovisnosti o dozi nakon primjene na štakorima. Pokusnim životinjama intraperitonealno je injiciran klozapin $(2,5,5,0$ i 10,0 mg kg-1) ili risperidon $(1,0,2,5$ i 5,0 mg kg-1). Nakon jednog sata životinje su žrtvovane i uzeti su uzorci mozga. Nakon primjene lijeka ili fiziološke otopine praćeni su hipolokomotorički učinci (aktivnost u kavezu i katalepsija). Oba lijeka su pri visokim dozama značajno smanjila $(p<0,01)$ lokomotoričku aktivnost, a smanjenje je ovisilo o dozi. Maksimalni (100 \%) kataleptički učinak postignut je visokom dozom risperidona $\left(5,0 \mathrm{mg} \mathrm{kg}^{-1}\right)$. Neurokemijske procjene provedene su pomoću HPLC s elektrokemijskom detekcijom. Oba lijeka su pri svim dozama značajno $(p<0,01)$ povećala koncentraciju homovanilinske kiseline (HVA), metabolita dopamina (DA), u striatumu. Koncentracija dihidroksifeniloctene kiseline (DOPAC) u striatumu bila je povećana, a u ostatku mozga smanjena, posebno nakon primjene klozapina. Koncentracija 5-hidroksiindol octene kiseline (5-HIAA), najvažnijeg metabolita serotonina, značajno $(p<$ $0,01)$ se smanjila u striatumu. 5-Hidroksitriptamin (5-HT) značajno se povećao $(p<0,01)$ nakon risperidona, a smanjio nakon klozapina u ostalim dijelovima mozga. Risperidon je značajno smanjio triptofan (TRP) u striatumu $(p<0,01)$, a povećao njegovu koncentraciju u ostalim dijelovima mozga. Također je povećao omjer HVA/DA u striatumu, dok je metabolizam 5-HT ostao nepromijenjen u ostalim dijelovima mozga. Rezultati upućuju na to da je interakcija ispitivanih lijekova $\mathrm{s}_{2} / 5-\mathrm{HT}_{1 \mathrm{~A}}$ receptorima uključena u nisku incidenciju ekstrapiramidalnih nuspojava. Razmatrana je uloga $5-\mathrm{HT}_{1 \mathrm{~A}}$ receptora $\mathrm{u}$ terapiji šizofrenije.

Ključne riječi: atipični antipsihotici, dopaminski $\mathrm{D}_{2}$ receptori, ekstrapiramidalne nuspojave, serotoninski $_{1 \mathrm{~A}}$ receptori, šizofrenija

Neurochemistry and Biochemical Neuropharmacology Research Laboratory, Department of Biochemistry, University of Karachi, Karachi-75270, Pakistan

Department of Biomedical Engineering, Sir Syed University of Engineering and Technology, Karachi, Pakistan 